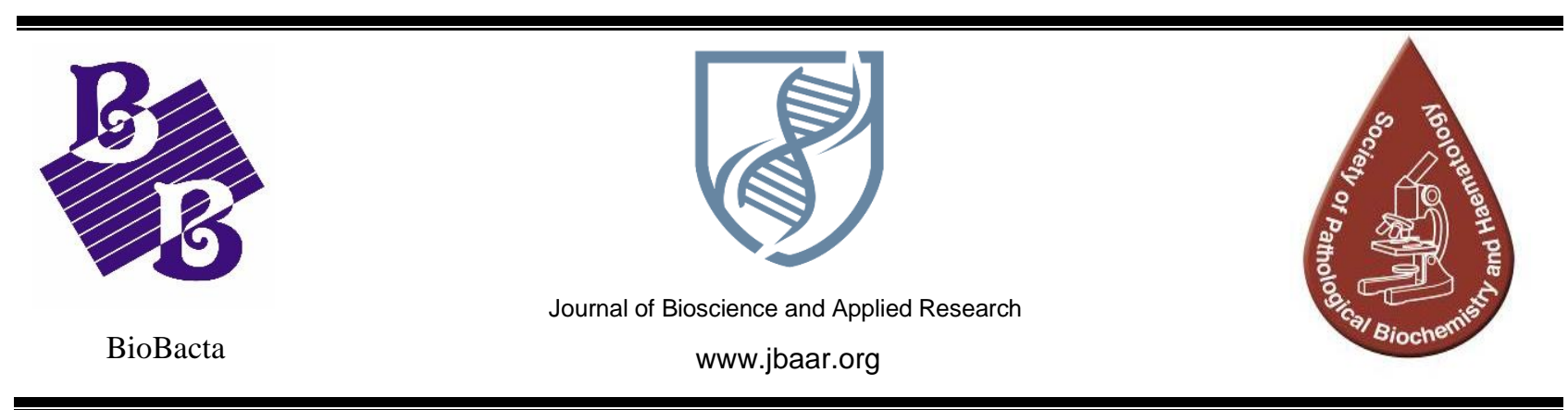

\title{
The curative effect of Cymbopogon citrates volatile oil against chlorambucil drug toxicity
}

\author{
ZakariaTeleb $^{1}$, KamiliaTaha ${ }^{2}$, Sobhy Hassab El-Nabi ${ }^{3}$, Islam El-Garawani ${ }^{3}$, Gouda T. \\ Dawoud $^{2}$, Samraa S. El-Shafey ${ }^{3}$, and Hanaa M. El-Esawy ${ }^{3}$ \\ ${ }^{1}$ Department of Biochemistry, National Organization for Drug Control and Research, MHP, Egypt. \\ ${ }^{2}$ Department of Phytochemistry, National Organization for Drug Control and Research, MHP, Egypt \\ ${ }^{3}$ Department of Zoology, Faculty of Science, Menoufia University, Egypt.
}

DOI: $10.21608 /$ JBAAR.2019.141385

\begin{abstract}
Chlorambucil (CLB) is a bifunctional alkylating drug widely used as an anticancer agent and immunosuppressant. CLB mutagenicity, teratogenicity, and carcinogenicity are indicated based on their structure and clinical history. This study aims to evaluate the antigenotoxic effect of Cymbopogon citratus essential oil, CC, $(75 \mathrm{mg} / \mathrm{kg})$ against CLB $(7.5 \mathrm{mg} / \mathrm{kg})$ genotoxicity in rats. GC/MS for essential oil has identified 19 compounds representing approximately 99.7\% Geranial was the most abundant (53.5\%) followed by Neral (35\%) and Myrcene (5.3\%). The lowest was $\alpha$-Muurolene (0. 1\%). The marked damage was observed in total genomic DNA and total protein profile of CLB-intoxicated rat's spleen tissues. Lymphocytes single-strand breaks of treated rats were examined by comet assay after CC had ameliorated these effects in a time-dependent manner $(5,10$, and 15 days) for spleen and after 48 hours for lymphocytes. In conclusion, this study suggests that Cymbopogon citrates oil possesses antigenotoxic potential in CLBintoxicated rats. It can constitute natural, new, and safe co-therapeutics.
\end{abstract}

Keywords: Chlorambucil; Cymbopogon citratus; DNA damage; Comet assay; GC/MS and essential oil.

Received date: March 15, 2019. Accepted: June 10, 2019, Published: June 12, 2019 


\section{Introduction}

Chlorambucil (CLB) is a bifunctional aromatic alkylator. It is used clinically as an anticancer drug and immunosuppressant. CLB kills cells, nonselectively (Thomas et al., 2000). It was found to inhibit transcription and translation. DNA is a critical molecule in the mode of action of mustards (Masta et al., 1995). Besides, chlorambucil was found to be carcinogenic in ${ }^{B A L B} / \mathrm{c}$ mice (Cavaliere et al., 1990). It was reported that the drug-induced DNA alkylation/damage lesions were singlestranded (DNA mono-adducts) or double-stranded (DNA inter-strand cross-links) (Wang et al., 2003).

Chlorambucil induces both crosslink DNA in the absence of metabolism (McLean et al., 1980) and monoalkylate DNA following metabolic removal of one of its chloroethyl groups (Adams et al., 1996). It induces ${ }^{32} \mathrm{P}$-labeled DNA adducts in calf thymus DNA used as a target for the direct detection of adducts (Yourtee et al., 1992). It induced interchromosomal mitotic recombination in the $w / w^{+}$ assay in Drosophila (Vogel and Nivard, 1993). CLB also caused chromosomal aberrations and micronucleus test after $48 \mathrm{~h}$ of spleen cells treatment (Moore et al., 1995), and In vitro chromosomal aberrations induction and sister-chromatid exchanges in a dose-dependent manner in V79 cells (Speit et al., 1992).

Natural compounds are considered chemoprotective agents against anticancer therapyinduced cytotoxicity in normal tissues (Guerriero et al., 2014; Sobhy et al., 2017; El-Garawani et al., 2017). They possess anticancer potential against different types of cancers (El-Nabi et al., 2018; Elkhateeb et al., 2018). The carcinogenic, mutagenic, and toxic effects caused by some medications could be diminished by natural compounds such as essential oils due to their accessibility and nontoxic effect on human cells and the environment (Huang et al., 2000; Lee et al., 2001; Sakr et al., 2016). Cymbopogon citratus essential oil is one of these chemopreventive agents (Melo et al., 2001). It has no toxic properties when daily administrated, for two months, to male and female rats and in offspring exposed "in utero" (Souza-Formigoni et al., 1986).

The CC oil is characterized by high percentages of citral (70-85\%) according to the geographical area (Ferreira and Fonteles, 1989) as determined by the GC-Mass method. It was found that citral (20 $\mathrm{mg} / \mathrm{kg}$ ) had significantly decreased the frequency of micronucleus induced by the known mutagens in the bone marrow and peripheral blood erythrocytes (Rabbani et al., 2005). A good superoxide scavenging activity was observed in citral-treated groups, too (Rabbani et al., 2006).

Kauderer et al. (1991) concluded that $\beta$ - myrcene was negative for the induction of point mutations in vitro and showed no induction of any chromosomal aberrations in cultured human peripheral blood lymphocytes. No carcinogenicity data on $\beta$ myrcene were located. It was generally negative for genotoxic activity in mammalian in vitro and in vivo (Roscheisen et al., 1991; Kauderer et al., 1991; Zamith et al., 1993).

Finally, the current study was conducted to evaluate the curative and antigenotoxic effect of Cymbopogon citratus against genetic disorders induced by CLB in the spleen as a target organ, because of its importance for human immunity.

\section{Materials and Methods}

\subsection{Materials}

\subsubsection{Chlorambucil (LEUKERAN)}

Chlorambucil is water-soluble aromatic nitrogen mustard, 4-[bis (2-chloroethyl) amino] benzenebutanoic acid. It was purchased from a local pharmacy. Tablets of Leukeran $2 \mathrm{mg}$ (GlaxoWellcome, UK) were dissociated and suspended in tap water. A concentration of 7.5 $\mathrm{mg} / \mathrm{kg} /$ day was administered daily to rats by a gastric tube (Tomenendalova et al., 2008).

\subsubsection{Volatile oil of Cymbopogon citratus (CC)}

The plant was obtained from National Organization for Drug Control and Research (medicinal plant field) at Kafr El- Gabal, Giza, 
Egypt. Extraction of total volatile oils from fresh lemongrass leaves was done by hydrodistillation method according to (Egyptian Pharmacopoeia, 1984). The oil was mixed with corn oil $(1: 5 \mathrm{v} / \mathrm{v})$ and a concentration of $75 \mathrm{mg} / \mathrm{kg} /$ day was administered daily to rats using a gastric tube (Fandohan et al., 2008).

\subsubsection{Experimental animals}

The present study was carried out using adult male albino rats (Rattus norvegicus) with an average body weight of about $170 \pm 10 \mathrm{~g}$. Animals were obtained from the National Organization for Drug Control and Research at Kafr El-Gabal, Giza, Egypt. Animals were acclimatized for two weeks in the animal house as established by Institutional Animal Ethical Committee (IAEC) at the Zoology Department, Faculty of Science, Menoufia University.

\subsubsection{Experimental design}

Initially, 15 animals were treated with 7.5 $\mathrm{mg} / \mathrm{kg} / \mathrm{day}$ of Chlorambucil as a preliminary study to investigate the effect of the drug as a toxicant, while other 15 untreated animals served as a control group (five animals at each dissection at fixed intervals, $5^{\text {th }}, 10^{\text {th }}$ and $15^{\text {th }}$ days).

The other experimental animals were divided into five groups, five animals each, like the following for DNA and protein analysis:

Control included corn oil (which received 200 $\mu \mathrm{l}$ of the commercial corn oil daily), CLB, CC oil, and $\mathrm{CC}$ oil as a curative agent against CLB toxicity (they received the oil dose after an hour of CLB dose. All groups were sacrificed by the $15^{\text {th }}$ day of treatment).

\subsection{Methods}

\subsubsection{Gas Chromatography/Mass Spectrometry (GC/MS)}

Identification of the oil constituents was performed on the Agilent 5989B, VL MS Detector system operating in EI mode (equipped with an HP5MS $30 \mathrm{~m} \times 0.25 \mathrm{~mm} \times 0.25 \mu \mathrm{m}$ film thickness capillary column), using $\mathrm{He}(1 \mathrm{ml} / \mathrm{min})$ as the carrier gas. $100 \mu \mathrm{l}$ of the EODM was diluted with
$400 \mu \mathrm{l}$ of dichloromethane and was injected into the GC-MS system in the split mode (split ratio 1: 33). Helium was used as the carrier gas with a flow rate of $0.7 \mathrm{ml} / \mathrm{min}$. The column temperature was maintained at $50^{\circ} \mathrm{C}$ for $2 \mathrm{~min}$. Then, it was programmed to $140^{\circ} \mathrm{C}$ at a rate of $3 / \mathrm{min}$, then it was increased up to $160^{\circ} \mathrm{C}$ at a rate of $0.5 / \mathrm{min}$ and the final temperature, $260^{\circ} \mathrm{C}$ at a rate of $3 / \mathrm{min}$, was held for $2 \mathrm{~min}$. Injector and detector temperatures were optimized at $230^{\circ} \mathrm{C}$ and $260^{\circ} \mathrm{C}$, respectively. The MS operating parameters were as follows: ionization energy, $70 \mathrm{eV}$; ion source temperature, $200^{\circ} \mathrm{C}$; quadruple, $100^{\circ} \mathrm{C}$; solvent delay, $8.0 \mathrm{~min}$; scan speed 2000/us and scan range 30-600 u, EV voltage 3000 volts. Determination of the components was based on direct comparison of the retention times and MS data with those for standard compounds, and matching with the combined Wiley 229, Nist 107, and Nist 21 libraries (Version 1998) (Adams, 2007).

\subsubsection{Total genomic DNA extraction and apoptosis detection}

DNA extraction and detection of apoptosis (DNA fragmentation assay) was done according to the "salting out extraction method" of Aljanabi and Martinez (1997) and modification by Hassab ElNabi (2004). Protein was precipitated by a solution of $\mathrm{NaCl}(4 \mathrm{M})$. Apoptotic bands of DNA fragmentation appeared and were located at $180 \mathrm{bp}$ and its multiples 360, 540, and 720 bp against 100bp DNA ladder (Thermo Scientific ${ }^{\mathrm{TM}}$ O'gene ruler $^{\mathrm{TM}}$ ). The intensity of released DNA fragments was analyzed using (Biogene software, France) as maximum optical density values where the height is a maximum intensity at 256 grey levels.

\section{Agarose gel electrophoresis}

The gel was prepared using $1.8 \%$ electrophoretic grade agarose (BRL) obtained from (Hispangar D-1 LE, Spain) (Surzycki, 2000a).

\section{Determination of DNA purity}

According to Surzycki (2000b), DNA purity was estimated spectrophotometrically at an optical 
density $\left(\mathrm{A}_{260} / \mathrm{A}_{280}\right)$, using (Nicolet Evolution 100, Thermo, England) spectrophotometer.

\subsubsection{Sodium dodecyl sulphate polyacrylamide gel electrophoresis (SDS-PAGE) of spleen tissues:}

SDS-PAGE was done according to Laemmli (1970) and the separation was done using the $12 \%$ continuous gel method.

\subsubsection{Alkaline single cell gel electrophoresis} (SCGE)/comet assay

\section{Leukocytes isolation}

Heparinized venous blood samples were drawn from treated and non-treated rats then blood was incubated twice by erythrocyte lysing buffer $(0.015$ $\mathrm{M} \mathrm{NH} 4 \mathrm{Cl}, 1 \mathrm{mM} \mathrm{NaHCO} 3,0.1 \mathrm{mM}$ EDTA). Cells then were resuspended in serum-free RPMI medium and forwarded to further investigations (El-Garawani, 2015).

Alkaline single cell gel electrophoresis (comet assay) was performed in this study (Singh et al., 1988). Briefly, cells were embedded into low melting point agarose gel between two layers of ultra-pure normal melting agarose on microscopic glass slides and immersed in lysis buffer $(2.5 \mathrm{M}$ $\mathrm{NaCl}, 100 \mathrm{mM}$ EDTA, and $10 \mathrm{mM}$ Tris, pH 10.0) with freshly added 1\% Triton X-100 (SigmaAldrich, Germany) and 10\% dimethyl sulfoxide (DMSO) for $1 \mathrm{~h}$ at $4^{\circ} \mathrm{C}$. Subsequently, the slides were incubated for $20 \mathrm{~min}$ in a cold and freshly prepared alkaline buffer $(300 \mathrm{mM} \mathrm{NaOH}$ and $1 \mathrm{mM}$ EDTA, $\mathrm{pH}>13$ ). The slides were applied in an electric current of $25 \mathrm{~V}$ and $300 \mathrm{~mA}$ for $10 \mathrm{~min}$. The slides were then neutralized for $3 \mathrm{~min}$ by $0.4 \mathrm{M}$ Tris-HCl buffer, $\mathrm{pH}$ 7.5. Next, they were stained with ethidium bromide (Sigma-Aldrich, Germany).
Visualization of cells was performed using a fluorescence microscope (Olympus BX 41, Japan), and representative images were photographed. For DNA damage assessment, about 200 randomly selected cells were examined per one field of total examined five fields. The results were divided as normal with no tail, damage with the migrated tail not more than the diameter of the nucleus, and strong damage with no distinct nucleus.

\subsection{Statistical analysis}

Data were presented as Mean \pm Standard Deviation $(\mathrm{M} \pm \mathrm{SD})$ for DNA and protein bands intensities. Comparisons were made between control (untreated) and treated individuals. Data statistically analyzed by using Student's $t$-test, (Mc Clave and Dietrich, 1991), $(P<0.05)$ were considered significant.

\section{Results}

\subsection{Cymbopogon citratus oil composition by GC/MS}

Cymbopogon citratus essential oil (i.e. > 1.5\% (V/W) is a volatile oil on a fresh weight basis). The gas chromatographic analysis results, coupled with the mass spectrometry of essential oil, identified 19 compounds. This represents approximately (99.7\%) as shown in Table (1) and reveals the presence of the following compounds: $\alpha$-Thujene, $\alpha$-Pinene, Myrcene, Limonene, (E) - $\beta$-Ocimene, Linalool, Citronellal, $\alpha$-Terpineol, Citronellol, Neral, Geraniol. Geranial, Geranyl acetate, $\beta$ Caryophyllene, $\alpha$-Humulene, $\alpha$-Muurolene, $\gamma$ Cadinene, and $\alpha$-Cadinol. Geranial presented the abundant $(53.5 \%)$ followed by Neral (35\%) and Myrcene (5.3\%) while the lowest was $\alpha$-Muurolene (0. $1 \%)$. 
Table 1. Essential oil (\%) identified in the oils of Cymbopogon citratus by GC/MS.

\begin{tabular}{|c|c|c|c|}
\hline No. & $\begin{array}{c}\text { Retention indices } \\
\text { (Literature) }\end{array}$ & Name & $\%$ \\
\hline 1 & 916 & $\alpha$ Thujene & 0.2 \\
\hline 2 & 929 & $\alpha$ Pinene & 0.5 \\
\hline 3 & 988 & Myrcene & 5.3 \\
\hline 4 & 1028 & Limonene & 0.6 \\
\hline 5 & 1045 & (E) - $\beta$-Ocimene & 0.3 \\
\hline 6 & 1095 & Linalool & 0.5 \\
\hline 7 & 1150 & Citronellal & 0.7 \\
\hline 8 & 1180 & $\alpha$ Terpineol & 0.3 \\
\hline 9 & 1230 & Citronellol & 0.2 \\
\hline 10 & 1242 & Neral & 35 \\
\hline 11 & 1256 & Geraniol & 0.9 \\
\hline 13 & 1273 & Geranial & 53.5 \\
\hline 14 & 1380 & Geranyl acetate & 0.5 \\
\hline 15 & 1416 & $\beta$-Caryophyllene & 0.4 \\
\hline 16 & 1447 & $\alpha$ Humulene & 0.2 \\
\hline 17 & 1495 & $\alpha$ Muurolene & 0.1 \\
\hline 18 & 1520 & $\gamma$ Cadinene & 0.2 \\
\hline 19 & 1650 & $\alpha$ Cadinol & 0.3 \\
\hline \multicolumn{3}{|c|}{ Total } & 99.7 \\
\hline
\end{tabular}

*Retention indices on HP-5MS 


\subsection{Total genomic DNA damage in CLB-treated rats}

CLB induced severe damage in the DNA of the spleen after fifteen days of treatment while nonsignificant damage was observed after five and ten days. There was an increase of the height value at
(1000 bp) which recorded 20 $\pm 2.9,24 \pm 2.2,27 \pm 1.9$, and $93 \pm 1.8$ for control, 5, 10, and 15 days, respectively. The third band (360 bp) has only a value for 15 days which recorded a height value of $30 \pm 2.3$. These results indicated that the highest DNA damage detected was for the treatment period of 15 days (Figure 1,2).

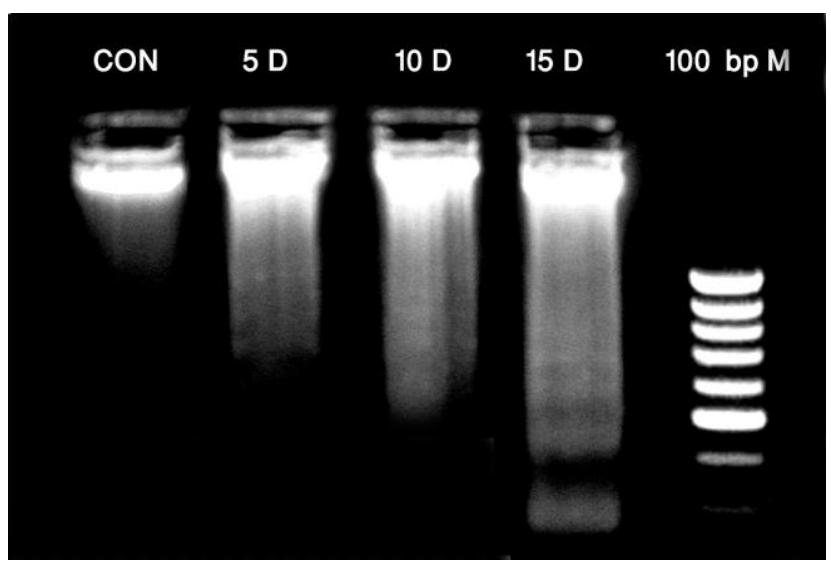

Figure (1): Photomicrograph of DNA electrophoresis of spleen tissues shows the effect of (CLB) (7.5 $\mathrm{mg} / \mathrm{kg} /$ day) after 5, 10, and 15 days of treatments, CON resembles control spleen; 5D: after 5 days; 10D: after 10 days; 15D: after 15days and M: 100 bp ladder.

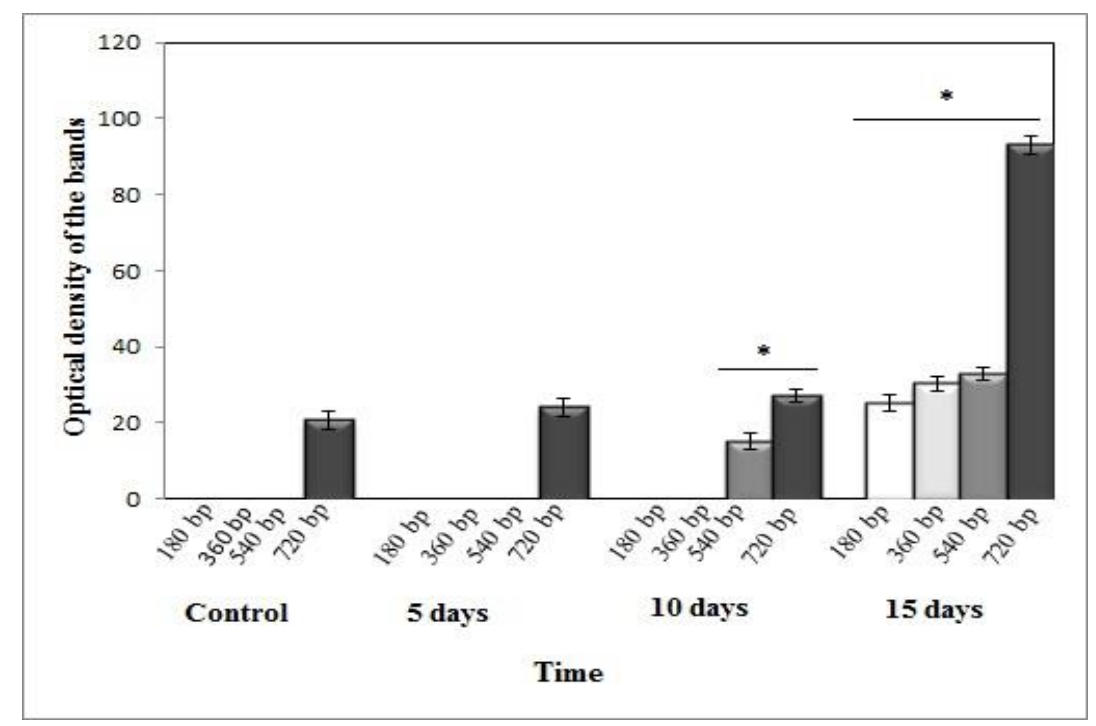

Figure (2): The average maximum intensity (height) of fragmented DNA in spleen treated with CLB after 5,10 , and 15 days. 


\subsection{The curative role of Cymbopogon citratus oil} against DNA damage induced by CLB after fifteen days

The curative effect was observed in all lanes when compared with control and corn oil lanes at the level of DNA fragmentation in spleen tissues.
Otherwise, CLB-treated animals countered the apoptotic DNA fragmentation at $(180,360,540$, and 720 bp) when compared with Cymbopogon citratus oil-treated groups (Figure 3,4).

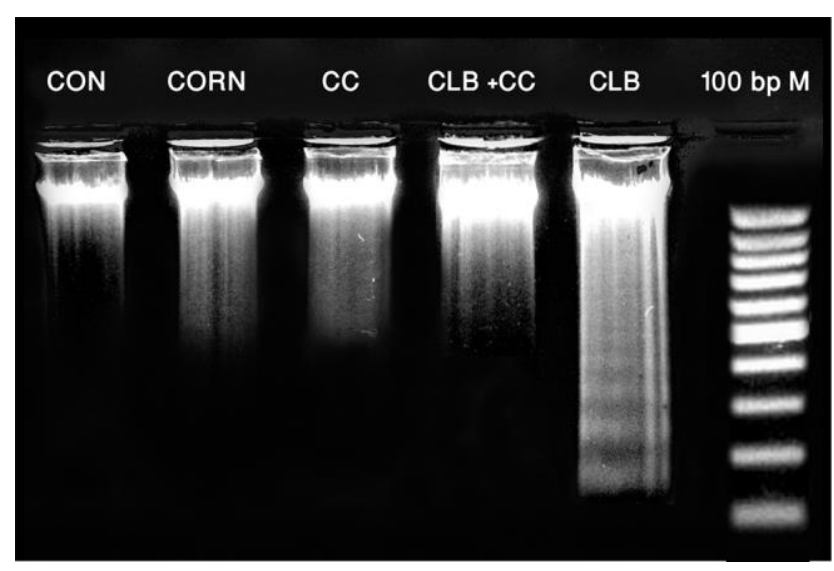

Figure (3): Photomicrograph of DNA electrophoresis of spleen tissues shows the effect of CLB (7.5 $\mathrm{mg} / \mathrm{kg} /$ day) and the curative effect of Cymbopogon citratus against CLB after fifteen days of treatment. CON resembles control; CORN: corn oil; CC: Cymbopogon citratus oil; CLB+CC: Cymbopogon citratus oil after one hour of (CLB) dosing and M: 100 bp ladder.

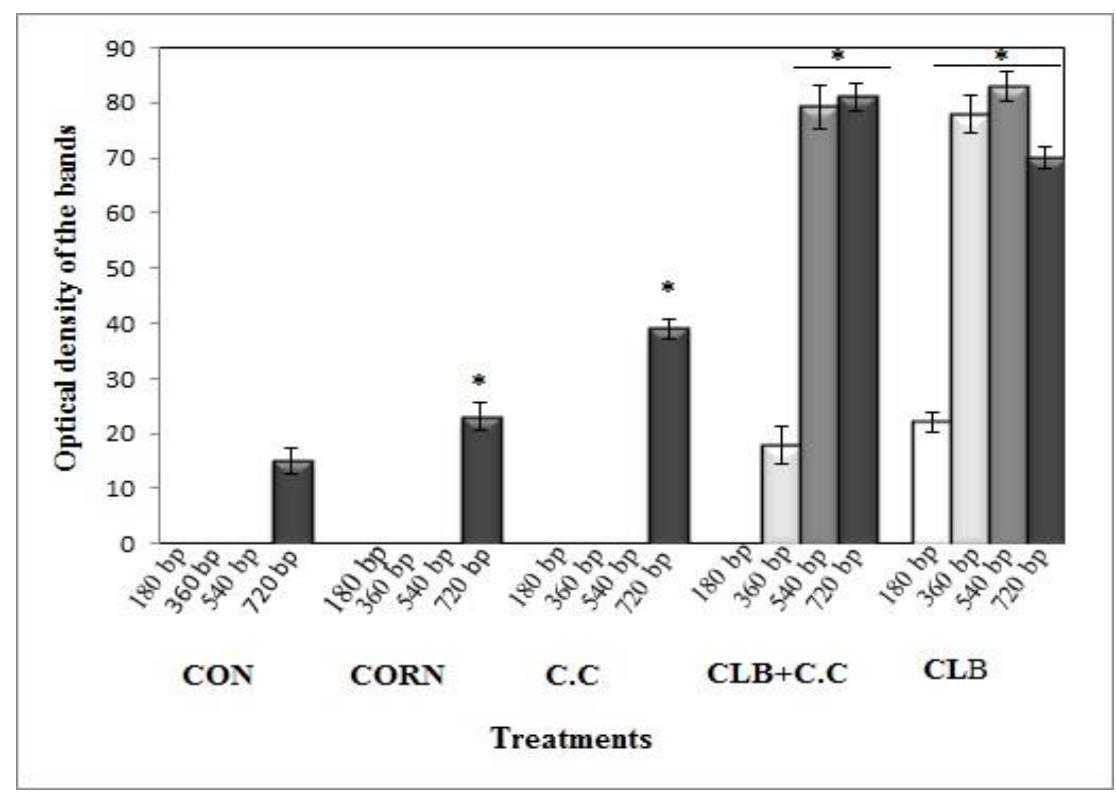

Figure (4): Maximum intensity $(\mathrm{M} \pm \mathrm{SD})$ of fragmented DNA in the spleen of animals treated with Cymbopogon citratus (CC) against CLB toxicity after 15 days. 


\subsection{DNA single-strand breaks (Comet assay)}

DNA single-strand breaks were detected as a length DNA migration tail. The length and intensity were classified as undamaged (normal), damaged $(+)$, and severely damaged cells $(++)$ with a fan-like tail. In this study, animals treated with CLB only showed severely damaged cells with a percentile value of $51 \pm 2.1 \%$ and damaged cells $39 \pm 2.9 \%$. On the contrary, CC-treated animals exhibited significant $(P<0.0005)$ genotoxic elevated effects, when compared with CLB, treated group. Data showed only about $6 \pm 1.1 \%$ severely damaged cells and $23 \pm 2.4 \%$ damaged cells (Figure 5\&6).

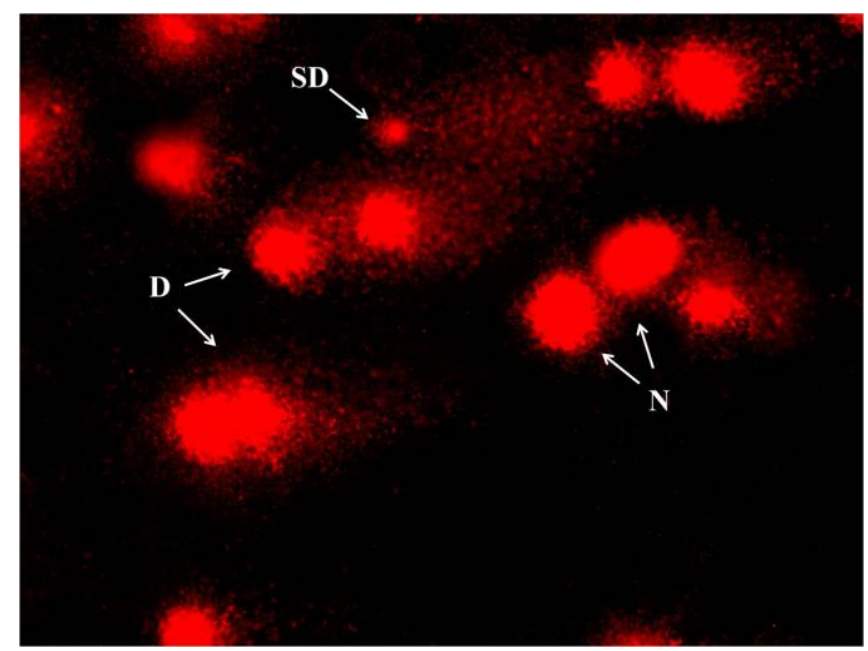

Figure (5): Photomicrograph showed single-strand breaks (comet assay or Single Cell Gel Electrophoresis assay) of DNA of rat leukocytes. (N) Normal DNA spots (no migration), (D) Damaged DNA spots (migration towards the anode), (SD) Strong damaged DNA spots (more migration towards the anode).

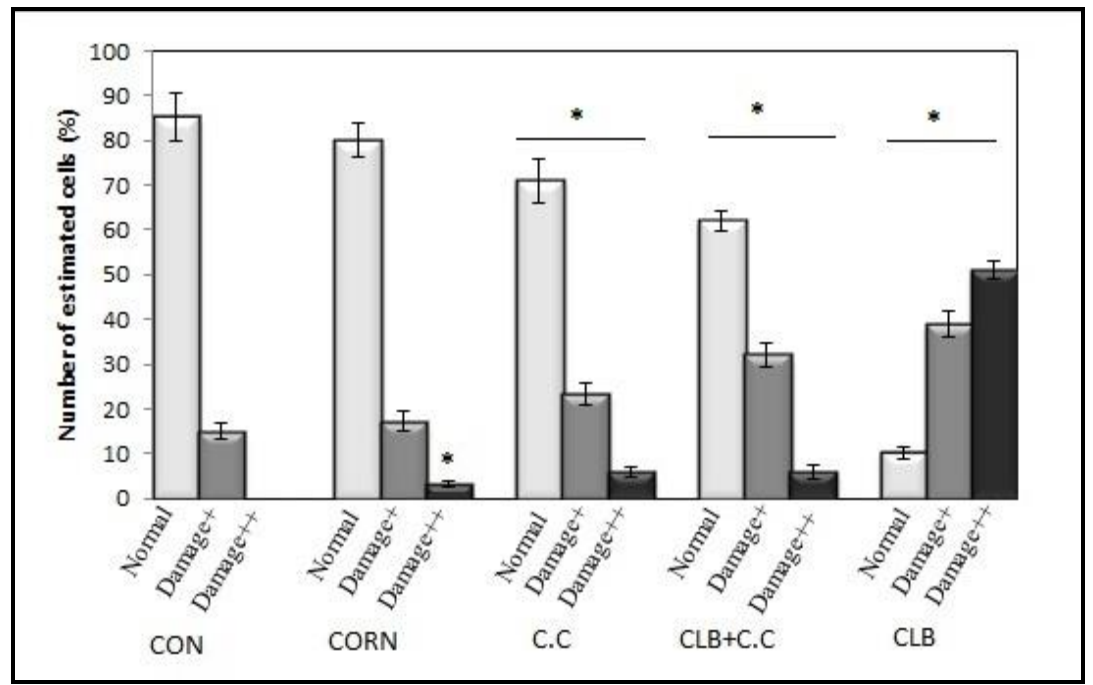

Figure (6): The effect on lymphocytes DNA damage of rat detected by comet assay after treatment with Cymbopogon citratus (CC) against CLB toxicity for 48 hours. 


\subsection{The curative role of $C C$ volatile oil against} CLB effect on total proteins of spleen tissues

Protein banding patterns of spleen tissues on $12 \%$ of SDS-PAGE after 15 days of treatments revealed that spleen tissues of CC-treated animals showed improved protein patterns when compared with CLB damaging effects (Figure 7).
Samples for control, corn oil, and CC showed no significant differences between protein bands among the electrophoretic migration; ranging between 26.6 and $180 \mathrm{kDa}$. On the contrary, there was an absence of three bands in CLB-treatments lanes. This was improved to only one absent lane in the CC-treated lane (Figure 7).

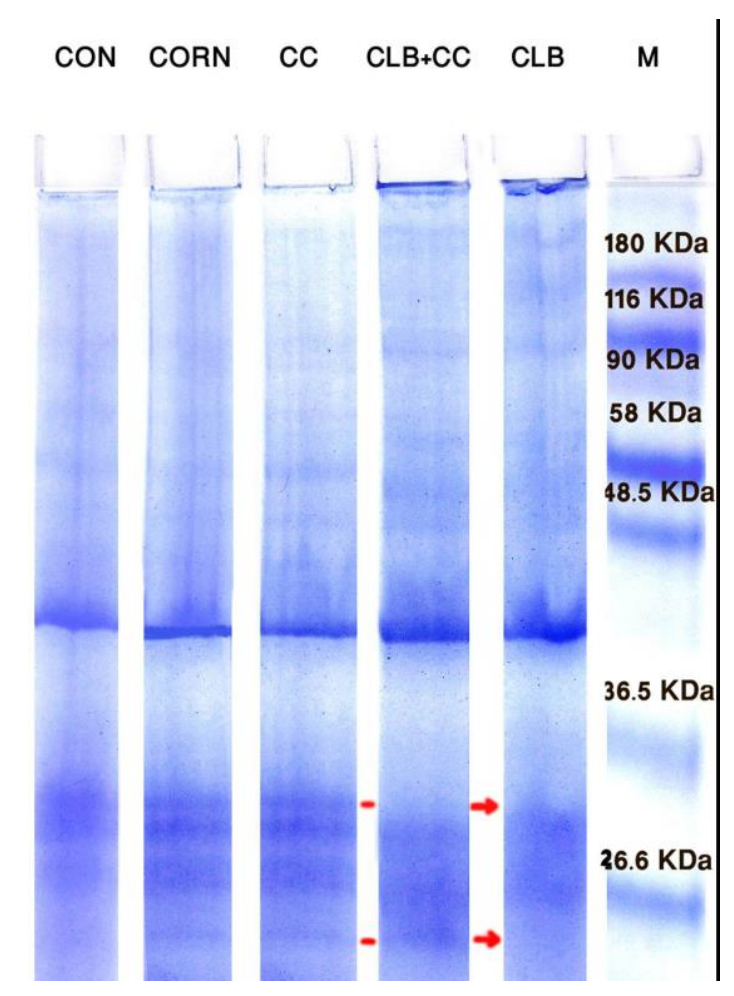

Figure (7): Photomicrograph of the spleen proteins profile by SDS-PAGE (12\%) showed the effect of CLB $(7.5 \mathrm{mg} / \mathrm{kg} /$ day) and the curative effect of Cymbopogon citratus (CC) against CLB after fifteen days of treatment. CON resembles control liver; CORN: corn oil; CC: Cymbopogon citratus oil; CLB+CC: Cymbopogon citratus oil after one hour of CLB dosing and M: (26.6 - $180 \mathrm{KDa})$.

\section{Discussion}

Mutations and DNA damage could be induced by drugs or irradiation commonly used in cancer treatment strategies. It not only kills cancer cells but also normal cells. One of these strategies is chemotherapy which is commonly used in cancer treatment.

Pre-carcinogenic lesions were found to be formed by covalent binding of alkylating agents (mutagens) to DNA (Miller and Miller, 1976). The
DNA adducts are formed as a result of the reaction of metabolically generated electrophilic ions with nucleophilic sites in DNA (Magee and Barnes, 1967). Chlorambucil is considered as one of the alkylating anticancer drugs. They stop tumor growth by cross-linking guanine bases in DNA double-helix strands preventing DNA replication and cell division (Rai et al., 2000).

Chlorambucil also leads to DNA damage via the formation of cross-links or mispairing of the 
nucleotides leading to mutations (Wishart et al., 2008). The most frequent location of adducts in the DNA is at guanines (Sanderson and Shield, 1996). Bank (1992) revealed that the majority of adducts induced by CLB are guanyl adducts. The reactivity of alkylating agents with DNA, RNA, and proteins can cause cell death. It is potentially carcinogenic, mutagenic, and teratogenic, and promotes secondary malignancies (Saffhill et al., 1985; Sanderson and Shield, 1996).

The present results showed that CLB induced mutagenic effects including DNA damage after fifteen days of treatment, while non-significant damage in the spleen was observed after five and ten days. Apoptosis as a cell death mode could be shifted towards necrosis by stimulation of genotoxic stimuli that are responsible for damaging the proteins or genes that make these proteins and other cellular macromolecules which may be required for apoptosis Singh (2000).

These results are in agreement with Bacsia et al., (2005) who mentioned that the induction of DNA double-strand breaks in CLB-exposed cells. Also, the present findings are in agreement with the results of Wang et al., (2003) which reported that the drug-induced DNA alkylation/damage lesions were single-stranded (DNA mono-adducts) or double-stranded (DNA inter-strand crosslinks).

Mughal et al., (2010) concluded that alkaline single cell gel electrophoresis (SCGE)/comet assay can successfully detect the genetic damage of peripheral blood. The results revealed that CLB induced severe damage in peripheral blood leukocyte cells when compared with normal cells. These results were in parallel with (Mughal et al., 2010), who reported the DNA damage occurs in the peripheral blood lymphocytes evaluated by comet assay between 36 and $48 \mathrm{~h}$ of CLB treatment in rats.

For thousands of years, physicians had believed that certain foods and plants had curative or restorative powers, and much of early medicine involved the prescription of certain foods or plant extracts to cure medical conditions (Stainmetz and Potter, 1991). The prevention of medication side effects is a worldwide interest. There have been many studies on the functionality of natural chemicals in foods and drinks.

The results of phytochemical investigation of lemongrass oil constituents by Gas Chromatographic-Mass Spectrometry (GC-MS) showed the presence of one major compound, citral, which is a mixture of the cis and trans-non-cyclic monoterpene aldehyde isomers, neral, and geranial. Myrcene was also detected. These results agree with most authors in this point of investigation with some geographical variations (Lewinsohn et al., 1998; Muhammad et al., 2003; Lewinsohn et al., 2005; Tchoumbougnang et al., 2005). These findings were found to be the reason for considering that lemongrass oil is one of the natural plants with antigenotoxic prosperities and protect cells from cell death and apoptosis.

In this study, results showed that $C$. citratus can exert preventive effects on the development of CLB mutagenic potential. Results of comet assay revealed that administration of $C$. citratus showed significant improvement by reduction of tail length and less DNA damaged cells percentage when compared with CLB treatment groups.

The curative effects of lemongrass may be due to the antioxidant activity or its ability to inhibit beta-glucuronidase activity (Suaeyun et al., 1997). Also, the chemoprevention associated with lemongrass volatile oil treatment is characterized by monoterpenes compounds and citral (Onawunmi et al., 1984; Rabbani et al., 2004). It is the major component (65-85\%) and consists of small quantities of monoterpene olefins, such as myrcene (Silva et al., 2008). Myrcene exerts its antimutagenic activity by inhibiting certain forms of the cytochrome P-450 isoenzymes required for activation of premutagens. Precarcinogenes is discussed too (Kauderer et al., 1991; Kim et al., 1992). 


\section{References}

Adams, S.P.; Laws, G.M.; Storer, R.D.; DeLuca, J.G. and Nichols, W.W. (1996): Detection of DNA damage induced by human carcinogens in cellular assays: potential application for determining genotoxic mechanisms. Mutat. Res., 368: 235-248.

Adams, R.P. (2007). Identification of Essential Oil Components by Gas Chromatography/Mass Spectrometry, 4th. Allured Pub. Corp., Carol Stream, IL. Allured Publishing Corporation: Carol Stream, IL.

Aljanabi, S.M., and Martinez, I. (1997): Universal and rapid salt-extraction of high quality genomic DNA for PCR-based techniques. Nucleic Acids Research, 25: 46924693.

Bacsia, A.; Kannana, S.; Leea, M-S.; Hazrab, T.K. and Boldogh, I. (2005): Modulation of DNA-dependent protein kinase activity in chlorambucil-treated cells. Free Radical Biology and Medicine, 39 (12): 1650-1659.

Bank, B.B. (1992): Studies of chlorambucilDNA adducts. Biochemical Pharmacology, 44 (3): 571-575.

Cavaliere, A.; Pietropaoli, N.; Alberti, P.F. and Vitali, R. (1990): Chlorambucil carcinogenesis in ${ }^{B A L B} / c$ mice. Cancer Letters, 55 (2): 115-120.

Egyptian Pharmacopoeia (1984): General Organization for Government Third edition, printing office, Cairo.

El-Garawani, I. M. (2015): Ameliorative effect of Cymbopogon citratus extract on cisplatininduced genotoxicity in human leukocytes. Journal of Bioscience and Applied Research,1(6), 304-310.
El-Garawani, I., El Nabi, S. H., \& ElGhandour, E., (2017): The protective effect of (Foeniculum vulgare) oil on etoposide-induced genotoxicity on male albino rats. Ejpmr, 4(7), 180-194.

Elkhateeb, W. A.; Zaghlol, G. M.; ElGarawani, I. M., Ahmed, E. F.; Rateb, M. E.; and Abdel Moneim, A. E. (2018): Ganoderma applanatum secondary metabolites induced apoptosis through different pathways: In vivo and in vitro anticancer studies. Biomedicine \& Pharmacotherapy, 101: 264-277.

El-Nabi, S. E. S. H.; Dawoud, G. T. M.; ElGarawani, I. M. and El-Shafey, S. S. (2018): HPLC analysis of phenolic acids, antioxidant activity and in vitro effectiveness of green and roasted Caffea arabica bean extracts: a comparative study. Anti-Cancer Agents in Medicinal Chemistry, 18: 1281 - 1288.

Fandohan, P.; Gnonlonfin, B.; Laleye, A.; Gbenou, J.D.; Darboux, R. and Moudachirou, M. (2008): Toxicity and gastric tolerance of essential oils from Cymbopogon citratus, Ocimum gratissimum and Ocimum basilicum in Wistar rats. Food and Chemical Toxicology, 46: 2493-2497.

Ferreira, M.S.C. and Fonteles, M.C. (1989): Aspectos etnobotanicos e farmacologicos do Cymbopogon citratus Stapf (capim limao). Revista Brasileira de Farmacia, 70: 94-97.

Guerriero, E.; Sorice, A.; Capone, F.; Napolitano, V.; Colonna, G.; Storti, G.; Costantini, S. (2014): Vitamin C Effect on Mitoxantrone-Induced Cytotoxicity in Human Breast Cancer Cell Lines. PLoS ONE, 9(12), e115287.

Hassab El-Nabi, S.E. (2004): Molecular and cytogenetic studies on the antimutagenic potential of eugenol in human lymphocytes 
culture treated with depakine and apetryl drugs. J. Egypt. Ger. Soc. Zool., 43(c): 171-196.

Huang, Y.; Lam, S.L. and Ho, S.H. (2000): Bioactivities of essential oils from Elletariacardamomum (L) to Sitohpilus zeamais Motschulsky and Tribolium castaneum (Herbst) Journal of Stored Products Research 36, 107 117.

Kauderer, B.; Zamith, H.; Paumgartten, F.J., and Speit, G. (1991): Evaluation of the mutagenicity of beta-myrcene in mammalian cells in vitro. Environmental and Molecular Mutagenesis, 18 (1): 28-34.

Kim, J.O.; Kim Y.S.; Lee, K.H.; Kim, M.N.; Rhee, S.H.; Moon, S.H. and Park, K.Y. (1992): Antimutagenic effect of the major volatile compounds identified from mugwort (Artemisia asictica nakai) leaves. J. Korean Soc. Food Nutr., 21(3): 308-313.

Laemmli, U.K. (1970): Cleavage of structural proteins during the assembly of the head of bacteriophage T4. Nature, 227: 680-685.

Lee, B.H.; Choi, W.S.; Lee, S.E. and Park, B.S.,( 2001): Fumigant toxicity essential oil and their consyiyuent compounds towards the rice weevil, Sitophilus oryzae (L). Crop prot. 20: 317-320.

Lewinsohn, E.; Dudai, N.; Tadmor, Y.; Katzir, I.; Ravid, U.; Putievsky, E. and Joel, D.M. (1998): Histochemical Localization of Citral Accumulation in Lemongrass Leaves (Cymbopogon citratus (DC.) Stapf., Poaceae). Annals of Botany, 81: 35-39.

Lewinsohn, E.; Sitrit, Y.; Bar, E.; Azulay, Y.; Ibdah, M.; Meir, A.; Yosef, E.; Zamir D. and Tadmor Y. (2005): Not just colors - carotenoid degradation as a link between pigmentation and aroma in tomato and watermelon fruit. Trends in Food Science \& Technology, 16 (9): 407-415.
Magee, P.N. and Barnes, J.M. (1967): Carcinogenic nitroso compounds. Adv. Cancer Res., 10: 163-246.

Masta, A.; Gray, P.J. and Phillips, D.R. (1995): Nitrogen mustard inhibits transcription and translation in a cell-free system. Nucleic Acids Research, 23 (17): 3508-3515.

McClave, J.T., and Dietrich, F.H. (1991): Statistics. Dellen Publishing Company, San Francisc, Fifth Edition: 629.

McLean, A.; Newell, D.; Baker, D. and Connors, T. (1980): The metabolism of chlorambucil. Biochemical Pharmacology, 29: 2039-2047.

Melo, S.F.; Soares, S.F.; Costa, R.F.; Silva, C.R.; Oliveira, M.B.N.; Bezerra, R.J.A.C.; Araújo, A.C. and Bernardo-Filho, M. (2001): Effect of the Cymbopogon citratus, Maytenus ilicifolia and Baccharis genistelloides extracts against the stannous chloride oxidative damage in Escherichia coli. Mutation Research/Genetic Toxicology and Environmental Mutagenesis, 496, (1-2): 33-38.

Miller, B.C., and Miller, J.A. (1976): The metabolism of chemical carcinogens to reactive electrophiles and their possible mechanisms of action in carcinogenesis. In: Searle, C.E. (ed), Chemical carcinogens. ACS Monograph 173, Washington,D.C.: 737-762.

Moore, F.R.; Urda, G.A.; Krishna, G. and Theiss, J.C. (1995): An in vivo/in vitro method for assessing micronucleus and chromosome aberration induction in rat bone marrow and spleen 2. Studies with chlorambucil and mitomycin C. Mutation Research / Environmental Mutagenesis and Related Subjects, 335 (2): 201-206.

Mughal, A.; Vikram, A.; Ramarao, P. and Jena, G.B. (2010): Micronucleus and comet 
assay in the peripheral blood of juvenile rat: Establishment of assay feasibility, time of sampling and the induction of DNA damage. Mutation Research/Genetic Toxicology \& Environmental Mutagenesis, 700 (1-2): 86-94.

Muhammad, S.; Nighat, A.; Aijaz, A.M.; Abdul, H.S.M.; Shaiq, A.M.; Shahida, S. and Ur-rahman, A. (2003): Chemistry and biological significance of essential oils of Cymbopogon citratus from Pakistan. Natural Product Research 17 (3): 159-163.

Onawunmi, G.O. Yisak, W.A.B. and Ogunlana, E.O. (1984): Antibacterial constituents in the essential oil of Cymbopogon citratus (DC.) Stapf. J. Ethnopharmacol. 12: 279-286.

Rabbani, S.I.; Devi, K. and Shivananda, T.N. (2004): Studies on antimutagenic effects of citral in mice. International journal of food, agriculture and environment, 2 (2): 62-64.

Rabbani, S.I.; Devi, K. and Zahra, N. (2005): Anti - Clastogenic Effects of Citral. Iranian journal of pharmacology \& therapeutics, 4: 2831.

Rabbani, S.I.; Devi, K.; Khanam, S. and Zahra, N. (2006): Citral, a component of lemongrass oil inhibits the clastogenic effect of nickel chloride in mouse micronucleus test system. Pak. J. Pharm. Sci., 19 (2): 108-113.

Rai, K.R.; Peterson, B.L.; Appelbaum, F.R.; Kolitz, J.; Elias, L.; Shepherd, L.; Hines, J.; Threatte, G.A.; Larson, R.A.; Cheson, B.D. and Schiffer, C.A. (2000): Fludarabine compared with chlorambucil as primary therapy for chronic lymphocytic leukemia. $N$ Engl $J$ Med., 343(24): 1750-1757.

Roscheisen, C.; Zamith, H.; Paumgartten, F.J.R., and Speit, G. (1991): Influence of $\beta$ myrcene on $\square$ sister-chromatid exchanges induced by mutagens in v79 and htc cells. Mutat. Res., 264(1): 43-49.

Saffhill, R.; Margison, G.P. and O'Connor, P.J. (1985): Mechanisms of carcinogenesis induced by alkylating agents. Biochim. Biophys. Acta, 823: 111-145.

Sakr, S.A., Hassab El Nabi, S.E., Okdah, Y.A., El-Garawani, I.M., and El-Shabka, A.M., (2016): Cytoprotective effects of aqueous ginger (Zingiber officinale) extract against carbimazole-induced toxicity in albino rats. European Journal of Pharmaceutical and Medical Research, 3 (7), 489-497.

Sanderson, B.J. and Shield, A.J. (1996): Mutagenic damage to mammalian cells by therapeutic alkylating agents. Mutation Research/Fundamental and Molecular Mechanisms of Mutagenesis, 355 (1-2): 41-57.

Silva, C.B., Guterres, S.S., Weisheimer, V. and Schapoval, E.E. (2008): Antifungal activity of the lemongrass oil and citral against Candida spp. Brazilian Journal of Infectious Diseases. 12 (1): 63-66.

Singh, N.P. (2000): A simple method for accurate estimation of apoptotic cells. Exper. Cell Res., 256: 328-337.

Singh, N.P.; McCoy, M.T.; Tice, R.R., and Schneider, E.L. (1988): A Simple technique for quantitation of low levels of DNA damage in individual cells. Exper. Cell Res., 175: 185191.

Sobhy E Hassab El Nabi, Islam M ElGarawani, Asmaa M Salman, Rania I Ouda (2017): The Possible Antigenotoxic Potential of Ginger Oil on Etoposide-Treated Albino Rats. Saudi Journal of Medical and Pharmaceutical Sciences, 3(7A): 693-703. 
Souza-Formigoni, M.L.; Lodder, H.M.; Gianotti Filho, O.; Ferreira, T.M.; Carlini, E.A. (1986): Pharmacology of lemongrass (Cymbopogon citratus Stapf). II. Effects of daily two month administration in male and female rats and in offspring exposed "in utero". Journal of Ethnopharmacology, 17 (1): 65-74.

Speit, G.; Menz, W.; Röscheisen, C. and Köberle, B. (1992): Cytogenetic and molecular characterization of the mutagenicity of chlorambucil in V79 cells. Mutation Research Letters, 283 (1): 75-81.

Steinmetz, K.A. and Potter, J.D. (1991): Vegetables, fruits and cancer. Epidermaiology. Cancer Causes Contro, 2: 352-357.

Suaeyun, R.; Kinouchi, T.; Arimochi, H.; Vinitketkumnuen U. and Ohnishi, Y. (1997): Inhibitory effects of lemon grass (Cymbopogon citratus Stapf) on formation of azoxymethaneinduced DNA adducts and aberrant crypt foci in the rat colon. Carcinogenesis, 18 (5): 949-955.

Surzycki, S. (2000a): Agarose Gel Electrophoresis of DNA in Basic Techniques in Molecular Biology (ed): 175-178.

Surzycki, S. (2000b): Isolation and Purification of RNA in Basic Techniques in Molecular Biology (ed): 119-139.

Tchoumbougnang, F.; Zollo, P.H.; Dagne, E. and Mekonnen, Y. (2005): In vivo antimalarial activity of essential oils from Cymbopogon citratus and Ocimum gratissimum on mice infected with Plasmodium berghei. Planta Medica , 71, (1): 20-23.
Thomas, A.; Pepper, C.; Hoy, T. and Bentley, P. (2000): Bcl-2 and Bax expression and chlorambucil-induced apoptosis in the T-cells and leukaemic B-cells of untreated B-cell chronic lymphocytic leukaemia patients. Leukemia Research, 24 (10): 813-821.

Tomenendalova, J.; Mayer, J.; Doubek, M.; Scheer, P.; Horky, D.; Rehakova, K. and Doubek, J. (2008): Toxicity of High-Dose Chlorambucil in Wistar Rats. Acta Vet. Brno, 77: 595-602.

Vogel, E.W. and Nivard, M.J.M. (1993): Performance of 181 chemicals in a Drosophila assay predominantly monitoring interchromosomal mitotic recombination. Mutagenesis, 8: 57-81.

Wang, Y-D.; Dziegielewski, J.; Wurtz, N.R.; Dziegielewska, B.; Dervan, P.B. and Beerman, T.A. (2003): DNA crosslinking and biological activity of a hairpin polyamidechlorambucil conjugate. Nucleic Acids Research, 31(4): 1208-1215.

Wishart, D.S.; Knox, C.; Guo, A.C.; Cheng, D.; Shrivastava, S.; Tzur, D.; Gautam, B. Hassanali, M. (2008): Nucleic Acids Res., 36. (Database issue): D901 - 6 [http: // www. drugbank. ca/ drugs / DB00888].

Yourtee, D.M.; Elkins, L.L.; Nalvarte, E.L. and Smith, R-L. (1992): Amplification of doxorubicin mutagenicity by cupric ion. Toxicol. Appl. Pharmacol., 116: 57-65.

Zamith, H.P., Vidal, M.N. Speit, G. and Paumgartten, F.J. (1993): Absence of genotoxic activity of $\beta$ myrcene in the in vivo cytogenic bone marrow assay. Braz. J. Med. Biol. Res., 26(1): 93-98. 